\title{
PENGEMBANGAN ASPEK KEAGAMAAN DI PAUD PERTIWI 7 DESA SUMBERREJO KECAMATAN BATANGHARI LAMPUNG TIMUR
}

\author{
Noormawanti \\ Universitas Muhammadiyah Metro \\ Noormawanti13@gmail.com
}

\begin{abstract}
This study discusses the Development of Religious Aspects in PAUD Pertiwi 7, Sumberrejo Village, Batanghari District, East Lampung Regency, with the following problem formulation: 1) How is the process of embedding religious values in the cultivation of religious aspects in PAUD Pertiwi 7, 2) How is the method applied in the context of inculcating religious values in the development of religious aspects in PAUD Pertiwi 7, 3) What are the supporting and inhibiting factors for planting religious values in developing religious aspects in PAUD Pertiwi 7. The purpose of this study is to describe how the development of religious aspects in PAUD Pertiwi 7 , Sumberrejo Village, Batanghari District, East Lampung.

The design of this research is to use a qualitative approach with a descriptive research model. So this research is a qualitative descriptive study. Data collection techniques using observation and interview methods. To further facilitate data exposure, categorization and organizing of data using a coding system is carried out. Research informants were obtained by snow ball sampling technique, then data validity testing was performed using triangulation methods. In data processing and data analysis done during and after conducting research.

The results of this study indicate that the Development of Religious Aspects in PAUD Pertiwi 7, Sumberrejo Village, Batanghari Subdistrict, East Lampung are: The process of planting religious values in the development of religious aspects in PAUD Pertiwi 7, Batanghari Village, East Lampung, is carried out by means of giving subject matter routinely in class. as a predetermined schedule. These materials include: Worship Material, Aqeedah Material, Moral Material. In delivering learning materials at school there are several methods used by teachers to implement religious values in the context of developing religious aspects including: Storytelling Method, Question and Answer Method, Recreation Method / Field Trip. In the learning process in the context of inculcating religious values in the development of religious aspects in Pertiwi 7 PAUD there are also supporting factors and inhibiting factors
\end{abstract}


which include: Supporting factors are Human Resources (HR) and environmental factors. The inhibiting factors are: Personality Factors and Time Limited Factors.

Keywords: Development, Religious Aspects.

\begin{abstract}
ABSTRAK
Penelitian ini membahas tentang Pengembangan Aspek Keagamaan di PAUD Pertiwi 7 Desa Sumberrejo Kecamatan Batanghari Kabupaten Lampung Timur, dengan rumusan masalah sebagai berikut: 1) Bagaimana proses penanaman nilai-nilai keagamaan dalam pengeambangan aspek keagamaan di PAUD Pertiwi 7, 2) Bagaimana metode yang diterapkan dalam rangka penanaman nilai-nilai keagamaan dalam pengembangan aspek keagamaan di PAUD Pertiwi 7, 3) Apa saja faktor pendukung dan penghambat penanaman nilai-nilai agama dalam pengembangan aspek keagamaan di PAUD Pertiwi 7. Tujuan penelitian ini adalah untuk menggambarkan bagaimana pengembangan aspek keagamaan di PAUD Pertiwi 7 Desa Sumberrejo Kecamatan Batanghari Lampung Timur.

Desain penelitian ini adalah menggunakan pendekatan kualitatif dengan model penelitian deskriptif. Sehingga penelitian ini adalah penelitian deskriptif kualitatif. Teknik pengumpulan datanya menggunakan metode observasi dan wawancara. Untuk lebih mempermudah pemaparan data maka dilakukan kategorisasi dan pengorganisasian data dengan sistem koding. Informan penelitian diperoleh dengan teknik snow ball sampling, kemudian pengujian keabsahan data dilakukan dengan menggunakan triangulasi metode. Pada pengolahan data dan analisis data dilakukan pada saat dan setelah melakukan penelitian.

Hasil penelitian ini menunjukkan bahwa Pengembangan Aspek Keagamaan di PAUD Pertiwi 7 Desa Sumberrejo Kecamatan Batanghari Lampung Timur adalah : Proses penanaman nilai-nilai agama dalam pengemabangan aaspek keagamaan di PAUD Pertiwi 7 Desa Batanghari Lampung Timur dilakukan dengan cara pemeberian materimateri pelajaran yangdiberikan secara rutin dikelas sebagaimana jadwal yang sudah ditentukan. Materi-materi tersebut anatara lain adalah :

Materi Ibadah, Materi Akidah, Materi Akhlak. Dalam menyampaikan materi pembelajaran disekolah ada beberapa metode yang digunakan oleh guru untuk menerapkan nilai-nilai agama dalam rangka pengembangan aspek keagamaan diantaranya adalah: Metode Bercerita, Metode Tanya Jawab, Metode Rekreasi/Karyawisata. Pada proses pembelajaran dalam rangka penanaman nilai-nilai agama dalam pengembangan aspek keagamaan di PAUD Pertiwi 7 juga terdapat faktor pendukung dan faktor penghambat yang antara lain adalah: Faktor Pendukungnya adalah sumber Daya Manusia (SDM) dan faktor lingkungan. Faktor Penghambatnya adalah: Faktor Kepribadian dan Faktor Terbatasnya Waktu.
\end{abstract}

Kata Kunci : Pengembangan, Aspek Keagamaan 


\section{A. PENDAhuluan}

Sebagai orang tua sudah semestinya selalu memperhatikan tumbuh kembang anak-anaknya, mulai dari merawat serta mendidik dan memilihkan lembaga pendiidkan yang terbaik bagi mereka. Hal ini dikarenakan seorang anak merupakan anugerah terbesar dan sekaligus sebagai generasi penerus bagi kedua orang tuanya serta bangsa dan negara.

Dalam siklus kehidupan manusia, masa kanak-kanak merupakan periode yang paling penting, namun sekaligus juga merupakan periode yang memerlukan perhatian dan kesungguhan dari pihak-pihak yang bertanggung jawab mengenai kehidupan anak-anak. Masa kanak-kanak merupakan sebuah periode pembentukan watak, kepribadian dan karakter dari seorang manusia agar mereka tidak memiliki kekuatan dan kemampuan serta mampu berdiri tegak dalam meniti kehidupan. ${ }^{1}$ Oleh sebab itu kedua orang tua dan pendidik dituntut untuk memenuhi kebutuhan anak-anak agar mereka terpelihara serta dapat menerapkan semua petunjuk dan pedoman yang diberikan kepada mereka untuk bekal kehidupan kelak dikemudian hari.

Berdasarkan hal tersebut maka jelas dapat kita ketahui bahwa peran orang tua sangatlah penting dalam pendampingan pola tumbuh kembang seorang anak. Pemikiran sosial dalam Islam setuju dengan sosial modern yang mengatakan bahwa keluarga merupakan unit pertama dan institusi pertama dalam masyarakat di mana hubungan-hubungan yang terdapat di dalamnya sebagian besar bersifat hubungan-hubungan langsung. Di sinilah berkembang individu dan terbentuknya tahap-tahap awal proses pemasyarakatan dan melalui interaksi dengannya ia memperoleh keterampilan, minat, nilai-nilai emosi dan sikapnya dalam hidup. Dengan itu ia memperoleh ketenteraman dan ketenangan. ${ }^{2}$

Tanggung jawab pendidik diselenggarakan dengan kewajiban mendidik. Secara

1 Abdul Razak Husain, “ Hak Anak Dalam Islam”, Jakarta: Fikahati Aniska, 1992, h. 13.

2 Hasan Langgulung "Manusia dan Pendidikan, suatu Analisa Psikologi dan Pendidikan", Jakarta: Al Husna Zikra , 1995, h. 346. 
umum mendidik ialah membantu anak didik di dalam perkembangan dari dayadayanya dan didalam penetapan nilai-nilai. Bantuan atau bimbingan itu dilakukan dalam penetapan nilai-nilai. Bantuann atau bimbingan itu dilakukan dalam pergaulan antara pendidik dan anak didik dalam situasi pendidikan yang terdapat dalam lingkungan rumah tangga, sekolah maupun masyarakat. Bimbingan itu adalah aktif dan pasif. Dikatakan "pasif” artinya sipendidik tidak mendahului "masa peka" akan tetapi menunggu dengan seksama dan sabar. Sedangkan bimbingan aktif terletak di dalam: (a) pengembangan daya-daya yang sedang mengalami masa pekanya, (b) pemberian pengetahuan dan kecakapan yang penting untuk masa depan si anak dan, (c) membangkitkan motif-motif yang dapat menggerakkan si anak untuk berbuat sesuai dengan tujuan hidupnya.

Pendekatan keagamaan dalam pendidikan anak dimaksudkan adalah bagaimana cara pendidik memproses anak didik melalui kegiatan bimbingan, latihan atau pengajaran keagamaan, termasuk di dalamnya mengarahkan, mendorong dan memberi semangat kepada anak agar taat dan mempunyai cita rasa beragama Islam, untuk mencapai tujuan pendidikan pada anak TK tersebut. ${ }^{3}$ Dalam proses pendidikan,metode mempunyai kedudukan yang sangat penting dalam upaya pencapaian tujuan karena ia menjadi sarana yang membermaknakan materi pelajaran yang tersusun dalam kurikulum pendidikan sedemikian rupa sehingga dapat dipahami atau diserap oleh manusia didik menjadi pengertianpengertian yang fungsional terhadap tingkah lakunya. ${ }^{4}$

Apabila metode, cara serta teknik yang digunakan pada lembaga Taman Kanak-kanak (TK) tidak sesuai dengan proses pembelajaran maka tujuan pendidikan untuk mencetak generasi akhlakul karimah sulit untuk dapat dicapai.

${ }^{3}$ Zakiah Darajat, "Ilmu Jiwa Agama", Jakarta: Bulan Bintang, 1996, h. 58.

${ }^{4}$ M. Arifin, "Ilmu Pendidikan Islam (suatu tinjauan Teoritis dan Praktis berdasarkan pendekatan Interdisipliner), Jakarta: Bumi Aksara, 2000, h. 197. 


\section{B. METODOLOGI PENELITIAN}

Jenis penelitian ini adalah kulaitatif-Deskriptif. ${ }^{5}$ Dalam penelitian ini penulis mengumpulkan data melalui riset lapangan dan riset perpustakaan yang dikumpulkan dari berbagai sumber. Adapun pendekatan yang peneliti gunakan adalah pendekatan fenomenologis, yaitu melihat dan merasa masuk kedalam dunia yang diteliti dengan begitu dapat mengerti yang terjadi di dalam situasi yang diteliti. ${ }^{6}$ Kemudian teknik pengumpulan data yang peneliti gunakan menggunakan pendekatan observasi, wawancara,

\section{HASIL PENELITIAN}

\section{A. Pengembangan Aspek Keagamaan Di PAUD Pertiwi 7 Desa Batanghari Lampung Timur}

\section{Proses penanaman nilai-nilai agama dalam pengeambangan aspek keagamaan di PAUD Pertiwi 7 Desa Batanghari Lampung Timur.}

Pendidikan agama akan lebih tepat jika dikembangkan ke arah internalisasi nilainilai keteladanan yang disertai engan aspek kognitif. Nilai-nilai yang diikuti secara bersamaan ini dapat menjadikan dorongan yang sangat kuat untuk mengamalkan dan menaati ajaran nilai-nilai dasar agama yang telah diinternalisasikan dalam diri anak sehingga dapat direfleksikan secara psikomotorik.

Pendidikan Islam lebih menonjolkan aspek nilai, baik nilai kebutuhan maupun kemanusiaan. Nilai-nilai inilah yang ditumbuh kembangkan ke dalam diri anak sehingga dapat melekat dalam kepribadiannya. Pelaksanaa pendidikan melalui penanaman nilai-nilai keteladanan yang dilakukan orangtua dan seorang guru diharapkan dapat menjadi proses pendidikan secara keseluruhan dalam membentuk kepribadian muslim sejati.

\section{a. Nilai Keimanan / Akidah}

Nilai keimanan/ akidah merupakan sinergi berbagai unsur aktivitas pedagogis;

${ }^{5}$ Masyuri M. Zainudin, “Metodologi Penelitian”, Bandung: PT Refika Aditama, 2008, h.12

${ }^{6}$ Lexy J. Moleong "Metodologi Penelitian Kualitatif” Bandung: PT Remaja Rosdakarya, 2000, h. 9 
pengaitan anak-anak dengan dasar-dasa keimanan, pengakrabannya dengan rukunrukun Islam, dan pembelajarannya tentang prinsip-prinsip syariat Islam. Pendidikan keimanan berarti melindungi aspek keimanan dari segala hal yang bisa mengotori keindahannya dan menimbulkan penyakit bagi pemiliknya, sekaligus membangun diri dengan beragam ibadah yang disyariatkan, membersihkannya dari kotorankotoran, dan menghiasinya dengan bermacam-macam keutamaan yang beragam.

Berdasarkan hasil observasi dan wawancara, di PAUD Pertwiwi 7 Desa Batanghari Lampung Timur menerapkan nilai-nilai agama dalam rangka pengembangan aspek keagamaan ini diberikan materi-materi ang terkait dengan penanaman nilai-nilai keagamaan yakni :

1. Nilai Keimanan/Akidah

2. Nilai Ibadah

3. Nilai Akhlak

Materi Pendidikan Aqidah meliputi:

a) Mengenalkan adanya malaikat-malaikat Allah, beserta tugas-tugasnya

b) Menceritakan tentang adanya Rasul Allah, tempat kelahiran, keluarga dan mukzizat-mukzizat yang dimiliki oleh para Rasul.

c) Mengenalkan adanya kitab suci yang diturunkan oleh Allah sebagai petunjuk bagi umat manusia, mengenalkan huruf Al-Qur'an serta bunyi dan cara membacanya.

Materi Pendidikan Ibadah meliputi:

a) Pendidikan Sholat, (gerakan, bacaan, perlengkapan yang digunakan dalam sholat).

b) Pendidikan Puasa, (niat puasa, latihan makan sahur, puasa hingga waktu berbuka.

c) Zakat, (mengenalkan pentingnya berbagi kepada sesama sebagai bentuk kepedulian kita terhadap orang lain) 
Materi Pendidikan Akhlak meliputi:

a) Akhlak kepada Allah, seperti berdo'a kepada Allah, mengerjakan sholat lima waktu, serta menghormati jika ada orang yang sedang mengerjakan sholat.

b) Akhlak terhadap orang tua dan sesama, seperti sopan santun, hormat terhadap orang tua, sopan santun terhadap sesama manusia.

c) Akhlak terhadap Alam semesta, seperti merawat tanaman yanga ada disekitar kita, memelihara binatang dan benda-benda yang ada disekitar kita.

\section{Metode yang diterapkan dalam rangka penanaman nilai-nilai agama dalam pengembangan aspek keagamaan di PAUD Pertiwi 7.}

Dalam pemilihan dan penerapan metode untuk proses belajar mengajar harus memperhatikan faktor-faktor yang mempengaruhinya. Diantaranya adalah tujuan, bahan/materi yang disampaikan, pendidik, anak didik, situasi, kelebihan, dan kelemahan metode dan sebagainya. Metode yang tepat dan baik ialah apabila dalam penerapannya metode tersebut mempunyai relevansi dengan tujuan, bahan atau materi pelajaran, dimensi perkembangan anak didik Dalam menyampaikan materi pembelajaran disekolah ada beberapa metode yang digunakan oleh guru untuk menerapkan nilai-nilai agama dalam rangka pengembangan aspek keagamaan diantaranya adalah:

a) Metode bermain. Bermain merupakan kegiatan yang memungkinkan anak memperoleh keberhasilan serta membantu perkembangan psikomotorik sang anak guna memperoleh keberhasilan dalam proses pembelajaran.

b) Metode Tanya jawab memang membantu bahasa anak tapi bagi anak kurang aktif di dalam kelas. Metode ini kurang ideal di karenakan anak bisa main sendiri, melamun atau mungkin mengantuk.

c) Metode rekreasi/karyawisata, metode ini kurang efektif untuk di gunakan . tapi membuat anak menjadi senang, dari segi waktu tidak efektif dari segi materi juga membutuhkan biaya yang tidak sedikit. Untuk itu metode ini dipakai sekali dalam satu tahun. 


\section{Apa saja faktor pendukung dan penghambat penanaman nilai-nilai agama dalam pengembangan aspek keagamaan di PAUD Pertiwi 7}

Berdasarkan wawancara yang dilakukan dengan guru dan kepala PAUD Pertiwi 7, bahwa yang menjadi faktor pendukung dan faktor penghambat dari penanaman nilai-nilai agama dalam pengembangan aspek keagamaan di PAUD Pertiwi 7 ini antara lain adalah:

1. Faktor Pendukung

a) Faktor SDM (Sumber Daya Manusia)

Guru yang dalam hal ini sebagai pendidik dan sekaligus sebagai penyampai materi kepada siswa yang memiliki kompetensi yang sesuai dengan bidangnya, sehingga memahami baik teknik maupun metode yang digunakan dalam menyampaikan materi sehigga mudah difahami oleh siswa.

b) Faktor Lingkungan

Faktor lingkungan antara lain adalah keluarga dalam hal ini adalah orang tua. Jika setelah diberikan materi-materi pendidikan terkait dengan penanaman nilainilai agama disekolah kemudian orang tua memberikan dukukngan dengan cara ikut mengingatkan dan mengamalkan dirumah maka akan memberikan hasil yang baik sesuai dengan tujuan yang telah ditetapkan.

\section{Faktor Penghambat}

a) Faktor Kepribadian

Faktor kepribadian dalam hal ini adalah kebiasaan si anak itu sendiri dimana ketika anak memiliki perhatian yang baik maka dia akan dengan senantiasa memperhatikan dan mengamalkan apa yang disampaikan oleh guru disekolah, tetapi apabila anak cenderung malas dan tidak memperhatikan maka dia tidak mau memperhatikan apalagi mengamalkan dalam kehidupan sehari-hari

b). Faktor Keterbatasan Waktu

Faktor Keterbatasan Waktu merupakan salah satu faktor penghambat dalam proses penanaman nilai-nilai aspek keagamaan di PAUD ini, terbatasnya waktu disekolah membuat apa yang telah diberikan dan disampaikan oleh guru 
kepada siswa menjadi kurang maksimal pengawasanya karena anak lebih banyak waktunya dirumah bersama orang tua dan keluarganya masing-masing. Sehingga dalam hal ini guru hanya bisa berusaha menyampaikan dengan semaksimal mungkin kepada anak dengan disertai contoh atau suri tauladan yang baik dengan harapan apa yang disampaikan itu dapat diterima oleh anak dan di praktekkan dalam kehidupan sehari-hari.

\section{KESIMPULAN}

Berdasarkan paparan yang telah dituliskan sebelumnya, maka penelitian ini dapat disimpulkan sebagai berikut :

1. Proses penanaman nilai-nilai agama dalam pengembangan aspek keagamaan di PAUD Pertiwi 7 Desa Batanghari Lampung Timur. Proses penanaman nilai-nilai agama dalam pengemabangan aaspek keagamaan di PAUD Pertiwi 7 Desa Batanghari Lampung Timur dilakukan dengan cara pemeberian materi-materi pelajaran yangdiberikan secara rutin dikelas sebagaimana jadwal yang sudah ditentukan. Materi-materi tersebut anatara lain adalah :
a) Materi Ibadah
b) Materi Akidah
c) Materi Akhlak

Materi Pendidikan Ibadah meliputi:

a) Pendidikan Sholat, (gerakan, bacaan, perlengkapan yang digunakan dalam sholat).

b) Pendidikan Puasa, (niat puasa, latihan makan sahur, puasa hingga waktu berbuka.

c) Zakat, (mengenalkan pentingnya berbagi kepada sesama sebagai bentuk kepedulian kita terhadap orang lain)

Materi pendiidkan Aqidah meliputi:

a) Mengenalkan adanya malaikat-malaikat Allah, beserta tugas-tugasnya

b) Menceritakan tentang adanya Rasul Allah, tempat kelahiran, keluarga dan mukzizat-mukzizat yang dimiliki oleh para Rasul. 
c) Mengenalkan adanya kitab suci yang diturunkan oleh Allah sebagai petunjuk bagi umat manusia, mengenalkan huruf Al-Qur'an serta bunyi dan cara membacanya.

Materi pendidikan Akhlak:

a) Akhlak kepada Allah, seperti berdo'a kepada Allah, mengerjakan sholat lima waktu, serta menghormati jika ada orang yang sedang mengerjakan sholat.

b) Akhlak terhadap orang tua dan sesama, seperti sopan santun, hormat terhadap orang tua, sopan santun terhadap sesama manusia.

c) Akhlak terhadap Alam semesta, seperti merawat tanaman yang ada disekitar kita, memelihara binatang dan benda-benda yang ada disekitar kita.

2. Metode yang diterapkan dalam rangka penanaman nilai-nilai agama dalam pengembangan aspek keagamaan di PAUD Pertiwi 7.

Dalam pemilihan dan penerapan metode untuk proses belajar mengajar harus memperhatikan faktor-faktor yang mempengaruhinya. Diantaranya adalah tujuan, bahan/materi yang disampaikan, pendidik, anak didik, situasi, kelebihan, dan kelemahan metode dan sebagainya. Metode yang tepat dan baik ialah apabila dalam penerapannya metode tersebut mempunyai relevansi dengan tujuan, bahan atau materi pelajaran, dimensi perkembangan anak didik

Dalam menyampaikan materi pembelajaran disekolah ada beberapa metode yang digunakan oleh guru untuk menerapkan nilai-nilai agama dalam rangka pengembangan aspek keagamaan diantaranya adalah: Metode Bercerita, Metode Tanya Jawab, Metode Rekreasi/Karyawisata.

3. Apa saja faktor pendukung dan penghambat penanaman nilai-nilai agama dalam pengembangan aspek keagamaan di PAUD Pertiwi 7

Dalam setiap proses kegiatan pastinya ada yang menjadi faktor pendukung dan juga faktor penghambat dari kegiatan tersebut, begitu halnya dengan proses pembelajaran dalam rangka penanaman nilai-nilai agama dalam pengembangan aspek 
keagamaan di PAUD Pertiwi 7 juga terdapat faktor pendukung dan faktor penghambat yang antara lain adalah:

a) Faktor Pendukung : Sumber Daya Manusia (SDM) dan faktor lingkungan

b) Faktor Penghambat : Faktor Keperibadian dan Faktor Terbatasnya Waktu.

\section{E. DAFTAR PUSTAKA}

Abdul Razak Husain, “ Hak Anak Dalam Islam”, Jakarta: Fikahati Aniska,

Hasan Langgulung "Manusia dan Pendidikan, suatu Analisa Psikologi dan Pendidikan”, Jakarta: Al Husna Zikra , 1995.

Imam al -Hafidz Abi Abbas Muhammad Ibn. Isa bin Saurah at-Tirmizi, Sunan at-Tirmizi al-Jami' us Sahih Juz-3, Semarang: Toha Putra, tt,

Joko Subagyo, "Metode Penelitian dalam Teori dan Praktek", Jakarta: Rineka Cipta, 1997.

Lexy J. Moleong, "Metodologi penelitian Kualitatif”, Bandung: PT Remaja Rosda Karya, 2014.

M. Arifin, " Ilmu Pendidikan Islam (suatu tinjauan Teoritis dan Praktis berdasarkan pendekatan Interdisipliner), Jakarta: Bumi Aksara, 2000

Muhammad Ali, "Strategi Penelitian Pendidikan", Bandung: Angkasa, 1993.

M. Burhan Bungin, "Penelitian kualitatif", Jakarta: Kencana Prenada Media Group, 2011.

Muhibbin Syah, "Psikologi Pendidikan dengan Pendekatan Baru”, Bandung, PT. Remaja Rosda Karya, 2000.

Masganti, Sit, “Psikologi Perkembangan Anak Usia Dini”, Jakarta: Kencana,

https://dosen psikologi. Com/tahap-perkembangan-beragama-pada-anak, h. 3.

M.A. Subandi, "Psikologi Agama dan Kesehataan Mental” Yogyakarta:

Pustaka Pelajar, 2013.

M. Athiyah al-Abrasy, "at-Tarbiyah al-Islamiyah wa falasatuha, Ttp: Isa alBabi al-Jalabi wa syirkahu, 1969. .

Mansur, "Pendidikan Anak", Jakarta: tp.

Masyuri, M. Zainudin, “Metodologi Penelitian”, Bandung: PT Refika Aditama, 2008.

Nurul Zuriah, “Metode Penelitian Sosial Dan Pendidikan”, Malang: Bumi Angkasara, 2007

Potensia : Jurnal Kependidikan Islam, Vol. 1 No. 2, Juli-Desember 2015.

Zakiah Darajat, “Ilmu Jiwa Agama”, Jakarta: Bulan Bintang, 1996. 